\title{
Assessment of Socio-Economic Status of Pochampally Ikat Handloom Weavers
}

\author{
V. Vijaya Lakshmi ${ }^{*}$, J. Deepika ${ }^{2}$ and M. Gayathri Devi ${ }^{3}$ \\ ${ }^{1}$ Department of FRM, AICRP (Home Science), PJTSAU, Hyderabad, India \\ ${ }^{2} S R F, A I C R P$ (Home Science), PJTSAU, Hyderabad, India \\ ${ }^{3}$ Department of Resource management and community sciences, College of community \\ science, PJTSAU, Hyderabad, India
}

*Corresponding author

\section{Ke y w o r d s \\ Ancient industry, Wooden devices, Cloth production, Urban sector \\ Article Info \\ Accepted: \\ 07 September 2019 \\ Available Online: \\ 10 October 2019}

\section{A B S T R A C T}

Handloom sector is an important second position employer in the country after agriculture by contributing to nearly $30 \%$ of total exports. Pochampally handloom weaving is very popular in Telangana state. Most of the pochampally ikat weavers are located in Nalgonda distrtict. Weaving is a family enterprise where right from the child to the old man in the family get involved in various weaving related activities. Hence a descriptive research design was adopted to study the socio-economic status of ikat weavers. A simple random sampling technique was adopted for selecting a total sample of 30 weavers consisting of 15 males and 15 females. Self-developed interview schedule was used to elucidate the information required. Income, educational qualification, and profession were taken into consideration to compute the socio economic status as per modified Kuppuswamy's socio economic scale 2018. Data was analyzed by frequency, percentage and correlation. The results of the study revealed that majority of female workers $(40 \%)$ were below 30 years old and about 33.3 per cent male workers belonged to the age group of 31- 40 years. Majority of female workers $(86.7 \%)$ and 80 per cent of male workers belonged to upper lower economic status. Relationship between socio-economic status of the weavers and personal variables of the study was assessed and it was found that there was a significant positive relationship between socio economic status with age, educational qualification and working hours at 0.01 level, because as age increases they gain more knowledge which in turn helps in earning more income, so their socio-economic status will also automatically increase. Similarly if their educational qualification was high then their socio economic status will also improve. Likewise if the weavers work for more hours then it affects their socio economic status.

\section{Introduction}

Handloom weaving is an ancient industry in India. In terms of the employment, it ranks only next to the agriculture providing livelihood to more than 40 million people. More than 16 million weavers are living based on handloom industry. According to the 
census 2011 it is estimated that 833 million people are currently living in rural India.

Among those people, now more than 35 million weavers and more than 150000 weaver's co-operative societies are built upon their dreams with the support of the handloom industry.

Weaving is the basic process among the various manufacturing stages of handloom clothes. It is defined as a frame for weaving equipped with some wooden devices.

The sound of the handloom is the music of rural home. This traditional rural and largest semi urban sector has widely spread its wings all over the country. One fourth of the total cloth production in the country is from the handloom sector and it has rightly been termed as an art and craft sector.

\section{Review of literature}

A study was conducted by Shamitha and Balasubramanian (2018) in Kannur district of Kerala on socio economic conditions of handloom weavers. This study was based on 37 weaver's co-operative societies in Kannur region, provide an employment opportunity to around 2600 members. These 37 weaver's societies were categorized to above average, average, below average. The major products of Kannur handloom were table linen, kitchen linen, bed linen, furnishing articles, curtains, toilet linen and fabrics. Government intervention of this sector is endless. A lot of welfare measures and schemes were introduced by government. In spite of various schemes implemented for the improvement of handloom industry, still it is facing lot of problems i.e. competition from global marketing, low level of income and poor market price, hence socio- economic conditions of weaving communities are not improved.
A study on socio economic status of handloom weavers was conducted by Gayathri Devi (2018) in Warangal urban district. Findings revealed that gender ratio in the occupation were $3: 1$. Most of the young adult and middle aged women weavers were involved in weaving and the percentage was significantly higher than men weavers. There was a significant positive relationship between socio economic status and BMI, $\mathrm{r}(118)=0.0512$, $\mathrm{p}$ $<0.1$. It can be concluded that individuals who spend active time on weaving will earn more amount of remuneration, so automatically socioeconomic status of the individual will be enhanced.

Srinivasa Rao and Sreedhar (2017) studied about "socio economic condition of handloom weavers in Gannavaram Mandal of Krishna district in Andhrapradesh. This study was based on extensive field work indicates that though handloom weaving has many strengths and can be competitive under specific conditions, the seeds of the crisis are inherent in this sector. These can be traced to two major factors i.e. the low performance of the co-operative sector and the very low economic condition of the weavers.

Elango and Nagaraj (2017) conducted a study to compare the socio-economic conditions of handloom weavers and occupational shifted persons in Palakkad district of Kerala. The results revealed that 34 per cent of weavers were in below SSLC and only 16 per cent passed it. But 50 per cent of occupational changed persons have passed SSLC and 14 per cent of them go to higher education. This led them to enlarge their job prospects. About 27 per cent of job changed persons were living in R.C houses. Whereas 40 per cent of weavers earned below Rs. 200 which was the only reason for thinking of shifting to some other job. More than 50 per cent of job shifted persons earned above Rs.200 per day. 
Rari John and Kamini (2016) had conducted a study on "socio economic status of women entrepreneurs in handloom sector". In this study they found that the traditional weaver community was not active in the field in Trivandrum district.

All the caste and communities were involved in weaving activities. Working conditions were pathetic. The sheds accommodated 8-10 looms which were too close to each other. Most of the sheds were open, with unfinished floors, low roofs, thatches, tin sheet, cramped with pit looms and without proper lighting.

Lakshmi Devi (2014) observed the socio economic conditions by portraying the weavers' house construction status, average daily income and number of persons engaged in weaving, type of ration card possessed etc. The study revealed that socio-economic conditions are very weak compared to other jobs.

Nagaraju and Viyyanna Rao (2014) conducted a study on the socio economic conditions of handloom weavers. The present study revealed the fact that majority of the respondents prefer gold work and Government service as an occupation for their children. The income of the weaver households determines the standard of living and financial status. In the study area, all the weavers were dependent on weaving for their livelihood. Majority (77 per cent) of the respondents were earning wages below $` 50,000$ per annum. Among the different types of weaver households, the independent weavers and weavers working for cooperatives are able to save some income than the weavers working for master weavers. Chit Funds and Post Office were the only institutions with which the respondents made their savings. It was found that 51.2 per cent of the respondents have availed of loan from master weavers, since they have been working for master weavers, and the moneylenders accounted for 24.3 per cent and 5.1 per cent of the respondents were borrowing from their friends or relatives.

Srinivasa Rao (2012) examined the financial performance of weavers' cooperative societies on uplifting the socio-economic conditions on weavers. It illustrated the structure of handloom industry, production and marketing trends prevailing in this sector. Due to lack of financial strength, most of the weavers did not repay the loans taken by money lenders. They were in the edge of suicide. Most of societies were in loss and getting closed down slowly.

\section{Materials and Methods}

Descriptive research design was adopted for the present study. Since weaver's community is reduced in weaving ikat fabrics in the last one decade and some of them have shifted to power looms, small sample comprised of 15 male and 15 female weavers were chosen from Koyalagudem village, Choutuppal mandal, Nalgonda district of Telangana state. Purposive sampling technique was followed based on the willingness of the sample to participate in the research study. Selfdeveloped interview schedule was used to elicit the information required. Income, educational qualification, and profession were taken into consideration to compute the socioeconomic status as per modified Kuppuswamy's socio economic scale 2018. Data was analysed by frequency, percentage and correlation.

Majority of the female workers (40\%) were in the age group of below 30 years and equal percentage of male workers (33.3\%) belonged to the age group of 31- 40 years and above 51 years. Least percentage of female workers (13.3\%) belonged to the age group of above 51 years and below 30 years. This indicates that majority of the workers engaged in the handloom weaving were the middle aged 
group coming under 30-40 years (Table 1). Marital status is one of the important factors that affect the social status of the people the difference in needs etc. The study revealed that majority $(86.7 \%)$ of female workers was married and only 13.3 per cent of female workers were unmarried. Almost (100\%) all the male workers were married (Table 2).

From the distribution of educational qualification, it was found that majority of female workers $(53.3 \%)$ and male workers $(33.3 \%)$ were illiterates. Only 13.3 per cent of male and female weavers had studied up to intermediate (Table 3).

About 40 per cent of female workers were having below 10 years experience and 53.3 per cent of male workers were having 11-20 years of experience (Table 4). However an equal percentage (40\%) of male and female workers had experience between 21 to 31 years.

Regarding monthly income, 80 per cent of female workers and 73.3 per cent of male workers were earning Rs.2092 - Rs.6213. Twenty per cent of female workers and 26.7 per cent of male workers were earning Rs. 6214-Rs. 10356 (Table 5). No one was earning income above 10356 rupees per month.

From the distribution of working hours, it was found that 73.3 per cent of female workers and 66.6 per cent of male workers were working for 6-8 hours per day (Table 6). And only 13.3 per cent of female workers and 6.7 per cent of male workers were working for less than 6 hours. However little more than one-fourth of male weavers were working for more than 8 hours a day.

Body mass index was assessed based on the respondent's weight and height. About 93.3 per cent of female workers and 66.6 per cent of male workers had normal body weight. Only 6.6 per cent of female workers had over weight and 6.7 per cent of male workers had obesity-class I (Table 7). It implies that since most of the weaving related activities demand squatting and sitting postures, workers need to get up and sit on the floor due to which most of them had normal weight.

Socio economic status of the respondents was calculated by considering education, occupation and total monthly income of the family as per Kuppuswamy scale. Results revealed that 86.7 per cent of female workers and 80 per cent of male workers belonged to upper lower economic status (Table 8).

Least percentage of female workers (13.3\%) and male workers (20\%) belonged to lower middle class. In other words, it can be stated that probably weavers are not well paid for the effort they put in weaving.

Relationship between socio-economic status of the weavers and personal variables of the study was assessed (Table 9). It was found that there was a significant positive relationship between socio economic status with age, educational qualification and working hours at 0.01 level, because as age increases they gain more knowledge, productivity would be more, so their socioeconomic status will also be automatically increased. Similarly if their educational qualification is high then their socio economic status also will improve. Likewise if the weavers work for more hours then it affects their socio economic status. There was no significant relationship between socio economic status with gender, marital status, work experience and body mass index.

It can be concluded from the study that the majority of female and male workers were aged between 30-40 years and were married. Male workers were better educated compared to female workers. 


\begin{tabular}{|c|c|c|}
\hline \multicolumn{3}{|c|}{ Table.1 Distribution of respondents by age } \\
\hline Age in years & $\begin{array}{c}\text { Female }(\mathrm{n}=15) \\
\mathrm{F}(\%)\end{array}$ & $\begin{array}{c}\text { Male }(\mathrm{n}=15) \\
\mathrm{F}(\%)\end{array}$ \\
\hline Below 30 years & $6(40.0 \%)$ & $2(13.3 \%)$ \\
\hline Between 31-40 years & $4(26.6 \%)$ & $5(33.3 \%)$ \\
\hline Between 41-50 years & $3(20.0 \%)$ & $3(20.0 \%)$ \\
\hline Above 51 years & $2(13.3 \%)$ & $5(33.3 \%)$ \\
\hline
\end{tabular}

\begin{tabular}{|c|c|c|}
\hline \multicolumn{2}{|c|}{ Table.2 Distribution of respondents by marital status } \\
\hline Marital Status & $\begin{array}{c}\text { Female }(\mathrm{n}=15) \\
\mathrm{F}(\%)\end{array}$ & $\begin{array}{c}\text { Male }(\mathrm{n}=15) \\
\mathrm{F}(\%)\end{array}$ \\
\hline Unmarried & $2(13.3 \%)$ & -- \\
\hline Married & $13(86.7 \%)$ & $15(100 \%)$ \\
\hline
\end{tabular}

\begin{tabular}{|c|c|c|}
\hline Table.3 Distribution of respondents by educational qualification \\
\hline Educational qualification & $\begin{array}{c}\text { Female }(\mathrm{n}=15) \\
\mathrm{F}(\%)\end{array}$ & $\begin{array}{c}\text { Male }(\mathrm{n}=15) \\
\mathrm{F}(\%)\end{array}$ \\
\hline Illiterate & $8(53.3 \%)$ & $5(33.3 \%)$ \\
\hline Primary school education & $1(6.7 \%)$ & $3(20.0 \%)$ \\
\hline Middle school education & $4(26.7 \%)$ & $1(6.7 \%)$ \\
\hline Higher school education & -- & $4(26.7 \%)$ \\
\hline Intermediate & $2(13.3 \%)$ & $2(13.3 \%)$ \\
\hline Graduate or post graduate & -- & \\
\hline Profession or honors & -- & -- \\
\hline
\end{tabular}

\begin{tabular}{|c|c|c|}
\hline \multicolumn{3}{|c|}{ Table.4 Distribution of respondents by work experience } \\
\hline Work experience & $\begin{array}{c}\text { Female }(\mathrm{n}=15) \\
\mathrm{F}(\%)\end{array}$ & $\begin{array}{c}\text { Male }(\mathrm{n}=15) \\
\mathrm{F}(\%)\end{array}$ \\
\hline Below 10 years & $6(40.0 \%)$ & $1(6.7 \%)$ \\
\hline Between 11-20 years & $3(20.0 \%)$ & $8(53.3 \%)$ \\
\hline Between 21-30 years & $4(26.7 \%)$ & $3(20.0 \%)$ \\
\hline Above 31 years & $2(13.3 \%)$ & $3(20.0 \%)$ \\
\hline
\end{tabular}

\begin{tabular}{|c|c|c|}
\hline \multicolumn{3}{|c|}{ Table.5 Distribution of respondents by monthly income } \\
\hline Monthly Income in Rs. & $\begin{array}{c}\text { Female }(\mathrm{n}=15) \\
\mathrm{F}(\%)\end{array}$ & $\begin{array}{c}\text { Male }(\mathrm{n}=15) \\
\mathrm{F}(\%)\end{array}$ \\
\hline $\mathbf{2 2 0 9 1}$ & -- & -- \\
\hline $\mathbf{2 0 9 2 - 6 2 1 3}$ & $12(80.0 \%)$ & $11(73.3 \%)$ \\
\hline $\mathbf{6 2 1 4 - 1 0 3 5 6}$ & $3(20.0 \%)$ & $4(26.7 \%)$ \\
\hline $\mathbf{1 0 3 5 7 - 1 5 5 3 5}$ & -- & -- \\
\hline $\mathbf{1 5 5 3 6 - 2 0 7 1 4}$ & -- & -- \\
\hline $\mathbf{2 0 7 1 5 - 4 1 4 2 9}$ & -- & -- \\
\hline
\end{tabular}




\begin{tabular}{|c|c|c|}
\hline \multicolumn{3}{|c|}{ Table.6 Distribution of respondents by working hours } \\
\hline Working hours & $\begin{array}{c}\text { Female }(\mathrm{n}=15) \\
\mathrm{F}(\%)\end{array}$ & $\begin{array}{c}\text { Male }(\mathrm{n}=15) \\
\mathrm{F}(\%)\end{array}$ \\
\hline Less than 6 hrs. & $2(13.3 \%)$ & $1(6.7 \%)$ \\
\hline 6-8 hrs. & $11(73.3 \%)$ & $10(66.6 \%)$ \\
\hline Above 8 hrs. & $2(13.3 \%)$ & $4(26.7 \%)$ \\
\hline
\end{tabular}

\begin{tabular}{|c|c|c|}
\hline \multicolumn{3}{|c|}{ Table.7 Distribution of respondents by body mass index } \\
\hline Body mass index & $\begin{array}{c}\text { Female }(\mathrm{n}=15) \\
\mathrm{F}(\%)\end{array}$ & $\begin{array}{c}\text { Male }(\mathrm{n}=15) \\
\mathrm{F}(\%)\end{array}$ \\
\hline Under weight (18.5 or less) & -- & $1(6.7 \%)$ \\
\hline Normal weight (18.5 to 24.99) & $14(93.3 \%)$ & $10(66.6 \%)$ \\
\hline Over weight(25 to 29.99) & $1(6.6 \%)$ & $3(20.0 \%)$ \\
\hline Obesity (class 1) (30 to 34.99) & -- & $1(6.7 \%)$ \\
\hline Obesity (class 2) (35 to 39.99) & -- & -- \\
\hline 40 or greater (Morbid obesity) & -- & -- \\
\hline
\end{tabular}

\begin{tabular}{|c|c|c|}
\hline \multicolumn{3}{|c|}{ Table.8 Distribution of respondents by economic status } \\
\hline Economic status & $\begin{array}{c}\text { Female }(\mathrm{n}=15) \\
\mathrm{F}(\%)\end{array}$ & $\begin{array}{c}\text { Male }(\mathrm{n}=15) \\
\mathrm{F}(\%)\end{array}$ \\
\hline Upper (26-29) & -- & \\
\hline Upper middle (16-25) & -- & \\
\hline Lower middle (11-15) & $2(13.3 \%)$ & $3(20.0 \%)$ \\
\hline Upper lower (5-10) & $13(86.7 \%)$ & $12(80.0 \%)$ \\
\hline Lower $(<\mathbf{5})$ & -- & \\
\hline
\end{tabular}

\begin{tabular}{|c|c|c|c|c|}
\hline \multicolumn{5}{|c|}{ Table.9 Relationship between personal variables and socio-economic status } \\
\hline $\begin{array}{l}\text { S. } \\
\text { No }\end{array}$ & Variables & $\mathrm{N}$ & $\begin{array}{l}\text { Correlation } \\
\text { Coefficient }\end{array}$ & Remarks \\
\hline 1. & Age with socio economic status & 30 & $0.005^{* *}$ & Significant \\
\hline 2. & Gender with socio economic status & 30 & $0.242^{\mathrm{ns}}$ & $\begin{array}{c}\text { Non- } \\
\text { Significant }\end{array}$ \\
\hline 3. & Marital status with socio economic status & 30 & $0.817^{\mathrm{ns}}$ & $\begin{array}{l}\text { Non- } \\
\text { Significant }\end{array}$ \\
\hline 4. & $\begin{array}{l}\text { Educational qualification with socio } \\
\text { economic status }\end{array}$ & 30 & $0.000^{* *}$ & Significant \\
\hline 5. & Work experience with socio economic status & 30 & $0.620^{\mathrm{ns}}$ & $\begin{array}{c}\text { Non- } \\
\text { Significant }\end{array}$ \\
\hline 6. & Working hours with socio economic status & 30 & $0.002^{* *}$ & Significant \\
\hline 7. & $\begin{array}{l}\text { Body mass index with socio economic } \\
\text { status }\end{array}$ & 30 & $0.823^{\mathrm{ns}}$ & $\begin{array}{c}\text { Non- } \\
\text { Significant }\end{array}$ \\
\hline \multicolumn{3}{|c|}{$\begin{array}{l}\text { *. Correlation is significant at the } 0.05 \text { level } \\
0.01 \text { level }\end{array}$} & \multicolumn{2}{|c|}{ **. Correlation is significant at the } \\
\hline
\end{tabular}


Majority of female workers $(86.7 \%)$ and 80 per cent of male workers belonged to upper lower economic status. There was a significant positive relationship between socio-economic status and age, educational qualification and working hours at 0.01 level. It implied that if education level is high and work for more hours, productivity would be automatically improved due to which socio-economic status will be better. Hence it is recommended that trainings need to be conducted by the Government in educating the weavers about new techniques and should take proper measures in enhancing their wage rate, encourage them by giving incentives for the best designs and promote handlooms through branded clothing stores by involving fashion designers to make the products more acceptable by the common man at affordable price.

\section{References}

Elango, D and Nagaraj, S. 2017. Compare the socio economic conditions of handloom weavers and occupational shifted persons in Palakkad district of kerala. International journal of informative and futuristic research. 5 (4): 8986-8992.

Gayathri Devi, M., Vijaya Lakshmi, V., Rajitha, I and Kameswari, S.L. 2018. Socio economic status of handloom weavers in Warangal urban district. International journal of current microbiology and applied sciences. 8(3):
Lakshmi Devi C.S, an analysis of socioeconomic status of handloom workers in India", International Journal of Business and Administration Research Review, Vol.3, Issue.5, April - June, 2014.

Lakshmi Devi C.S. 2014. An analysis of socio economic status of handloom workers in India. 3(5):16.

Naga raju, G and ViyyannaRao, K. 2014. A study on the socio economic conditions of handloom weavers. Journal of rural development. 33(3): 309-328.

Rari John, K and Kamini, S. 2016. Socio economic status of women entrepreneurs in handloom sector. International journal of applied home science. 3(11\&12): 459469.

Shamitha. K.B and Balasubramanian, P. 2018. Socio-economic condition of handloom weavers: A study with special reference to handloom weaver's co-operative society in Kannur district. International journal of pure and applied mathematics. 111(16): 1411-1423.

Srinivasa Rao Kasisomayajula, "Socioeconomic analysis of handloom industry in Andhra Pradesh: A Study on selected districts", Journal of Exclusive Magt. Science, Vol. 1, Issue 8, September, 2012.

Srinivasa Rao, D and Sreedhar, N. 2017. Socio economic condition of handloom weaver's in Gannavaram mandal of Krishna district in Andhra Pradesh. IOSR Journal of Humanities and social science. 22(9). 42-49.

\section{How to cite this article:}

Vijaya Lakshmi, V., J. Deepika and Gayathri Devi, M. 2019. Assessment of Socio-Economic Status of Pochampally Ikat Handloom Weavers. Int.J.Curr.Microbiol.App.Sci. 8(10): 573-579. doi: https://doi.org/10.20546/ijcmas.2019.810.063 